\title{
The impact of metabolic syndrome on the clinical profile and tumor characteristics of endometrial carcinoma
}

\author{
Tawfik A. Tawfik ${ }^{1}$, Bassma M. Elsabaa ${ }^{2}$, Dalia A. El-Neily ${ }^{3}$, Sally S. El-Tawab ${ }^{1} *$, \\ Heba A. Ebrahim ${ }^{1}$
}

\author{
${ }^{1}$ Department of Obstetrics and Gynaecology, Shatby Maternity University Hospital, Faculty of Medicine, Alexandria \\ University, Alexandria, Egypt \\ ${ }^{2}$ Department of Pathology, Faculty of Medicine, Alexandria University, Alexandria, Egypt \\ ${ }^{3}$ Department of Clinical and Chemical Pathology, Faculty of Medicine, Alexandria University, Alexandria, Egypt
}

Received: 07 September 2016

Accepted: 03 October 2016

*Correspondence:

Dr. Sally S. El-Tawab,

E-mail: sally_eltawab@hotmail.com

Copyright: () the author(s), publisher and licensee Medip Academy. This is an open-access article distributed under the terms of the Creative Commons Attribution Non-Commercial License, which permits unrestricted non-commercial use, distribution, and reproduction in any medium, provided the original work is properly cited.

\begin{abstract}
Background: The objective is to study the influence of different components of metabolic syndrome on clinical behavior and tumor characteristics of endometrial cancer cases and to evaluate if metformin usage affects the stage and grade of endometrial cancer.

Methods: 60 women attending the gynecological oncology clinic at El Shatby Maternity University Hospital, after being diagnosed as endometrial carcinoma, were recruited in the study. Serum samples were collected to detect insulin level and lipid profile, and then allocated into two groups according to metabolic syndrome existence. After the recommended surgery, and the routine histopathological diagnosis followed by histopathological chemilumeniscence technique to detect staining intensity, percentage of estrogen receptors ER, and score out of 8 according to Allred score.

Results: Endometrial cancer EC patients with metabolic syndrome had a significantly higher age, higher FIGO stages, and higher grade compared to EC without metabolic syndrome $(p<0.05)$. There was no statically significant difference between both groups in estrogen receptors scoring. HDL was an important factor affecting grade of EC patients, as when HDL decreased by one $\mathrm{mg} / \mathrm{dl}$, the grade increased by $0.033 \% \quad(\mathrm{P}=0.030, \mathrm{OR}=0.899$, OR adjusted=0.826), Insulin level was found to be an important factor affecting stage as when insulin level increased by one $\mathrm{Uiu} / \mathrm{ml}$, the stage increased by $1.091 \%(\mathrm{p}=<0.001, \mathrm{OR}=1.064$, OR adjusted $=1.091)$.

Conclusions: Hyperinsulinemia was the most important factor affecting aggressiveness of the tumor as regards stage and risk group classification. Metformin failed to show a protective effect against endometrial cancer progression.
\end{abstract}

Keywords: Allred score, Endometrial cancer, Estrogen receptors, Hyperinsulinemia, Metabolic syndrome

\section{INTRODUCTION}

Endometrial cancer is the most frequently occurring gynaecologic malignancy, It is the fourth most common cancer overall, and the seventh most common cause of cancer death for women in the United States, representing $6 \%$ of all cancer cases in women. ${ }^{1}$ Exposure to higher levels of endogenous or exogenous estrogens, plays a major role in endometrial carcinogenesis. ${ }^{2}$ A process leading to malignant disease with a peak in incidence after menopause. It has been shown that the concentration of estrogen receptors (ER) in endometrial carcinoma tissue was significantly higher than the concentration in normal endometrial. ${ }^{3}$ Obesity, a condition that exposes women to higher levels of estrogen produced in adipose tissue, is one of the major risk factors of endometrial 
cancer. Other conditions that have been shown to increase endometrial cancer risk independently of obesity, include diabetes mellitus and hypertension. ${ }^{4,5}$

The metabolic syndrome is a cluster of risk factors including obesity, hypertension, insulin resistance, and dyslipidemia. ${ }^{6}$ The metabolic syndrome has been defined using harmonized guidelines requiring presence of $>3$ of the following risk factors: Waist circumference $>88 \mathrm{~cm}$, triglycerides $>150 \mathrm{mg} / \mathrm{dl}$, HDL cholesterol $<50 \mathrm{mg} / \mathrm{dl}$, systolic blood pressure (BP) $>130$ or diastolic BP $>85 \mathrm{mmHg}$, or treatment of previously diagnosed hypertension, and fasting plasma glucose $>100 \mathrm{mg} / \mathrm{dl}{ }^{7}$

The potential biological link between the endometrial cancer and metabolic syndrome is incompletely understood and the mediators for this association are not known, but are thought to be related to hyperinsulinemia (either due to insulin resistance or due to administered insulin), hyperglycaemia, insulin like-growth factor, and adipocytokines. ${ }^{8}$ Moreover, evidence from observational studies suggests that some oral glucose lowering medications used to treat hyperglycaemia are associated with either increased or reduced cancer risk or mortality. ${ }^{9,10}$

The metabolic syndrome could be a means for identifying those at risk of endometrial cancer who might otherwise be missed or before any component of metabolic syndrome becomes more advanced. ${ }^{11}$

\section{METHODS}

\section{Subjects and study design}

After obtaining the approval of Alexandria faculty of medicine Ethics Committee on the study protocol, and an informed written consent from all participants, this study was conducted on sixty women (endometrial cancer cases, diagnosed by dilatation and curettage) admitted to El-shatby Maternity University Hospital in period from (June 2014 to December 2015).

\section{Inclusion criteria}

Women diagnosed as having endometrioid endometrial cancer of different grades by histopathological examination of endometrial tissue sample and fit for surgery were recruited. Then Patients were allocated into either of two groups:

Group 1: Women with endometrial cancer and fulfilling the criteria of the metabolic syndrome ( 32 women).

Group 2: Women having endometrial cancer but not fulfilling the criteria of the metabolic syndrome (28 women).

All patients had detailed history taking, including: age at menopause if reached, duration of abnormal uterine bleeding, reproductive history e.g. (PCO) and drug history e.g. (HRT and other hormones), and medical history including diabetes and hypertension. Physical examination: including general examination: Systolic and diastolic blood pressure reading will be obtained on several setting and mean pressure was calculated Calculation of BMI, and physical examination were done.

Blood samples were withdrawn for measurement of components of metabolic syndrome: TG, HDL, LDL, Cholesterol (total), Fasting blood glucose (FBG) which is measured by automated machine and the autobio insulin (INS) chemilumeniscence immunoassay (CLIA) kit is intended for the quantitative determination of insulin concentration in human serum (12). Blood was drawn using standard venipuncture technique and the serum was separated from the red blood cells as soon as practical. Grossly hemolytic, lipemic or turbid samples were avoided. Plasma samples collected in tubes containing EDTA, heparin, or oxalate could interfere with test procedures and were avoided. Specimens were capped and stored up to 48 hours at - 2 to $-80 \mathrm{C}$, prior to assaying, specimens held for a longer time were frozen at $-20 \mathrm{oC}$. Thawed samples were mixed prior to testing.

3 or more abnormalities were considered having metabolic syndrome. Preoperative imaging procedures including transvaginal ultrasound, chest $\mathrm{X}$ ray, multi-slice CT (MSCT) were done. All women had the recommended surgery of total abdominal hysterectomy with bilateral salpingooophorectomy \pm lymphadenectomy according to the recommendation and the estimated surgical hazards.

All removed tissue specimen were sent to the pathology department for detailed reporting of type, grade, myometrial invasion, lymphvascular space invasion and nodal status if any. In addition, Estrogen Receptor(ER) protein expression was detected using primary Monoclonal Mouse Anti-Human Estrogen Receptor $\alpha$, Clone 1D5 code catalogue number M704729, (Dako, s products, Denmark) using immunohistochemistry. ${ }^{13}$

\section{Statistical analysis of the data}

Data were fed to the computer and analyzed using IBM SPSS software package version 20.0. Qualitative data were described using number and percent. Quantitative data were described using range (minimum and maximum), mean, standard deviation and median. Significance of the obtained results was judged at the 5\% level. Odd ratio (OR):used to calculate the ratio of the odds and $95 \%$ Confidence Interval of an event occurring in one risk group to the odds of it occurring in the nonrisk group.

\section{RESULTS}

In our study, when classifying the women with EC according to the presence or absence of metabolic syndrome, group 1 (EC patients with MS) was 32, while group 2 (EC patients without MS) was 28 women, with no statistic significant difference between the two groups in relation to the number of patients included. 
In our study, we found that patients with EC and MS (group 1) had a statistically significant higher age than patients in group 2. All patients with MS (group 1) were multipara, with statistical significance $(\mathrm{p}=0.008)$, compared to $78.6 \%$ of group 2 .

Table 1: Comparison between both studied groups according to different parameters.

\begin{tabular}{|c|c|c|c|}
\hline & $\begin{array}{l}\text { Group } 1 \\
(\mathrm{n}=32)\end{array}$ & $\begin{array}{l}\text { Group } 2 \\
(n=28)\end{array}$ & $\mathbf{P}$ \\
\hline Age (years) & $\begin{array}{l}64.28 \pm \\
6.51\end{array}$ & $\begin{array}{l}58.46 \pm \\
9.83\end{array}$ & $<0.011^{*}$ \\
\hline BMI & $\begin{array}{l}36.51 \pm \\
5.53\end{array}$ & $\begin{array}{l}35.17 \pm \\
5.57\end{array}$ & 0.355 \\
\hline \multicolumn{4}{|l|}{$\begin{array}{l}\text { Obstetric } \\
\text { history }\end{array}$} \\
\hline Nulipara & $0(0.00 \%)$ & $6(21.4 \%)$ & $<0.008^{*}$ \\
\hline Multipara & $32(100 \%)$ & $22(78.6 \%)$ & $<0.008^{*}$ \\
\hline \multicolumn{4}{|l|}{$\begin{array}{l}\text { Menstrual } \\
\text { history }\end{array}$} \\
\hline $\begin{array}{l}\text { Still } \\
\text { menstruating }\end{array}$ & $0(0.00 \%)$ & $8(28.6 \%)$ & \multirow{2}{*}{$<0.001^{*}$} \\
\hline Post-menopausal & $32(100 \%)$ & $20(71.4 \%)$ & \\
\hline \multicolumn{4}{|l|}{ DM } \\
\hline Yes & $28(87.5 \%)$ & $4(14.3 \%)$ & $<0.001^{*}$ \\
\hline \multicolumn{4}{|l|}{ HTN } \\
\hline Yes & $30(93.8 \%)$ & $2(7.1 \%)$ & $<0.001^{*}$ \\
\hline Insulin level & $\begin{array}{l}38.64 \pm \\
17.09\end{array}$ & $\begin{array}{l}16.24 \pm \\
9.36\end{array}$ & $<0.001^{*}$ \\
\hline \multicolumn{4}{|l|}{ Lipid profile } \\
\hline HDL & $\begin{array}{l}20.56 \pm \\
7.79\end{array}$ & $\begin{array}{l}32.86 \pm \\
7.60\end{array}$ & $<0.001^{*}$ \\
\hline \multicolumn{4}{|l|}{ Grade } \\
\hline Grade 1 & $7(21.9 \%)$ & $16(57.1 \%)$ & $0.005^{*}$ \\
\hline Grade 2 & $16(65.6 \%)$ & $8(28.6 \%)$ & $0.004^{*}$ \\
\hline Grade 3 & $4(12.5 \%)$ & $4(14.3 \%)$ & 1.00 \\
\hline \multicolumn{4}{|l|}{ Stage } \\
\hline Stage 1 & $14(43.8 \%)$ & $20(71.4 \%)$ & \\
\hline Stage 2 & $9(28.1 \%)$ & $4(14.3 \%)$ & 0.97 \\
\hline Stage 3 & $9(28.1 \%)$ & $4(14.3 \%)$ & \\
\hline \multicolumn{4}{|l|}{ Risk groups } \\
\hline Low risk & $14(43.8 \%)$ & $14(50 \%)$ & \\
\hline Intermediate & $10(0.0)$ & $4(14.3 \%)$ & $0.049 *$ \\
\hline High & $18(56.3 \%)$ & $10(35.7 \%)$ & \\
\hline \multicolumn{4}{|l|}{ ER } \\
\hline \multicolumn{4}{|l|}{ Score(of 8) } \\
\hline Small & $0(0.0)$ & $2(7.1 \%)$ & 0.214 \\
\hline Moderate & $12(37.5 \%)$ & $10(37.5 \%)$ & 0.886 \\
\hline Good & $8(25.0 \%)$ & $10(37.5 \%)$ & 0.366 \\
\hline
\end{tabular}

Qualitative data were described using number and percent and was compared using Chi square test. Normally quantitative data was expressed as Mean \pm SD and compared using student t-test. While abnormally distributed data was expressed using Median (Min. Max.) and was compared using Mann Whitney test.
Regarding the menopausal state, $100.0 \%$ of group 1 were post-menopause and $71.4 \%$ of group 2 were post menopause. There was statistical significance between the studied groups according to menopausal state $(\mathrm{p}=0.001)$.

EC patients with MS presented at higher grade, higher stage and higher risk group classification with a statically significant difference $(\mathrm{p}<0.05)$, The Allred scoring system was employed to analyze intensity (out of 3), percentage of estrogen receptors (out of 5) and overall score out of 8 . There was no statically significant difference between both groups regards ER overall score, (Table 1).

In order to study the influence of different parameters of metabolic syndrome which include (BMI, HTN, Insulin level (hyperinsulinemia), HDL and TG) on aggressiveness of endometrioid endometrial cancer as regard (grade, stage and risk classification) and for the feasibility of statistical analysis, all patients were joined in one group. As regards grade: we classified grade into: low grade (grade I and grade $\mathrm{II}=52$ cases) and High grade $($ grade III $)=(9$ cases $)$. Then calculate odds ratio $(\mathrm{OR})$ and confidence interval (CI) of each parameter separately.

Table 2 and Figure 1 showed that, HDL was an important factor affecting grade of EC patients, as when HDL decreased by one $\mathrm{mg} / \mathrm{dl}$, the grade increased by $0.033 \%$ $(\mathrm{P}=0.030, \quad \mathrm{OR}=0.899$, OR adjusted $=0.826)$, in other words, a higher HDL is protective against EC.

As regard stage, we classified women into: -low stage (stage I) and High stage (stage II and stage III), no stage IV were included in our study.

Then calculate odds ratio (OR) and confidence interval (CI) of each parameter separately.

Insulin level was found to be an important factor affecting stage as when insulin level increased by one $\mathrm{Uiu} / \mathrm{ml}$, the stage increased by $1.091 \%$ $(\mathrm{p}=<0.001, \mathrm{OR}=1.064, \mathrm{OR}$ adjusted=1.091). So the higher the insulin levels the more aggressive the tumour, as regards stage (Table 3 and Figure 2).

As regards new risk group classification, we classified women into: low risk group including (Low risk and intermediate risk) and High risk group including (Intermediate-high and high risk). Then calculate odds ratio (OR) and confidence interval (CI) of each parameter separately.

It was found that insulin level was the most important factor affecting (risk classification) as when insulin level increased by one $\mathrm{Uiu} / \mathrm{ml}$, the risk group increased by $1.049 \%(\mathrm{P}=<0.001, \mathrm{OR}=1.048$ and $\mathrm{OR}$ adjusted $=1.049)$. The second most important factor was BMI as when BMI increased by one $\mathrm{Kg} / \mathrm{m} 2$, the risk increased by $1.103 \%$ $(\mathrm{P}=0.045, \mathrm{OR}=1.107)$ (Table 4, Figure 3). 
Table 2: Influence of the different components of metabolic syndrome on aggressiveness of endometrioid endometrial cancer (grade).

\begin{tabular}{|c|c|c|c|c|c|c|c|c|c|c|}
\hline & \multirow{2}{*}{$\begin{array}{l}\text { Grade 1-2 } \\
(\mathrm{n}=52)\end{array}$} & \multirow{2}{*}{$\begin{array}{l}\text { Grade } 3 \\
(\mathrm{n}=8)\end{array}$} & \multirow[t]{2}{*}{$\mathbf{P}$} & \multirow[t]{2}{*}{ OR } & \multicolumn{2}{|c|}{ CI 95\% } & \multirow{2}{*}{$\begin{array}{l}\text { p } \\
\text { adjusted }\end{array}$} & \multirow{2}{*}{$\begin{array}{l}\text { OR } \\
\text { adjusted }\end{array}$} & \multicolumn{2}{|c|}{$\begin{array}{l}\text { CI 95\% } \\
\text { adjusted }\end{array}$} \\
\hline & & & & & $\mathbf{L L}$ & $\mathbf{U L}$ & & & $\mathbf{L L}$ & $\mathbf{U L}$ \\
\hline HTN & $26(50 \%)$ & $6(75 \%)$ & 0.187 & 3.0 & 0.553 & 16.26 & 0.388 & 0.240 & 0.009 & 6.124 \\
\hline BMI & $35.96 \pm 5.94$ & $35.45 \pm 1.21$ & 0.588 & 0.983 & 0.858 & 1.127 & 0.590 & 0.947 & 0.777 & 1.155 \\
\hline Insulin level & $28.67 \pm 18.54$ & $25.04 \pm 13.59$ & 0.853 & 0.988 & 0.945 & 1.033 & 0.096 & 0.930 & 0.853 & 1.013 \\
\hline HDL & $27.46 \pm 9.58$ & $18.75 \pm 8.35$ & $0.030^{*}$ & $0.899 *$ & 0.817 & 0.988 & $0.033^{*}$ & $0.826^{*}$ & 0.693 & 0.985 \\
\hline TG & $98.79 \pm 56.65$ & $163.0 \pm 52.17$ & $0.012^{*}$ & $1.017 *$ & 1.004 & 1.030 & 0.071 & 1.020 & 0.998 & 1.043 \\
\hline
\end{tabular}

OR: Odds ratio; CI: Confidence interval ;LL: Lower limit; UL: Upper Limit; *Statistically significant at $\mathrm{p} \leq 0.05$

Table 3: The influence of the different components of the metabolic syndrome on aggressiveness of endometrioid endometrial cancer (stage).

\begin{tabular}{|c|c|c|c|c|c|c|c|c|c|}
\hline & \multirow[t]{2}{*}{ Grade 1} & \multirow[t]{2}{*}{ Grade 3} & \multirow[t]{2}{*}{$\mathbf{P}$} & \multirow[t]{2}{*}{ OR } & \multicolumn{2}{|c|}{ CI $95 \%$} & \multirow{2}{*}{$\begin{array}{l}\text { OR } \\
\text { adjusted }\end{array}$} & \multicolumn{2}{|c|}{$\begin{array}{l}\text { CI } 95 \% \\
\text { adjusted }\end{array}$} \\
\hline & & & & & $\mathbf{L L}$ & UL & & $\mathbf{L L}$ & UL \\
\hline HTN & $16(47.1 \%)$ & $16(61.5 \%)$ & 0.265 & 1.800 & 0.637 & 5.083 & 0.101 & 0.009 & 1.150 \\
\hline BMI & $35.15 \pm 5.44$ & $36.86 \pm 5.64$ & 0.239 & 1.059 & 0.963 & 1.166 & 1.060 & 0.938 & 1.197 \\
\hline Insulin level & $20.86 \pm 14.68$ & $37.76 \pm 17.44$ & $<0.001^{*}$ & $1.064^{*}$ & 1.026 & 1.103 & $1.091^{*}$ & 1.031 & 1.154 \\
\hline HDL & $28.21 \pm 9.99$ & $23.81 \pm 9.20$ & 0.090 & 0.953 & 0.901 & 1.007 & 0.928 & 0.835 & 1.032 \\
\hline TG & $111.76 \pm 59.91$ & $101.58 \pm 60.44$ & 0.420 & 0.997 & 0.988 & 1.006 & 0.995 & 0.983 & 1.008 \\
\hline
\end{tabular}

OR: Odds ratio; CI: Confidence interval ;LL: Lower limit; UL: Upper Limit; *Statistically significant at p $\leq 0.05$

Table 4: The influence of the different components of the metabolic syndrome on aggressiveness of endometrioid endometrial cancer (risk classification).

\begin{tabular}{|c|c|c|c|c|c|c|c|c|c|}
\hline & \multirow[t]{2}{*}{ Low risk } & \multirow[t]{2}{*}{ High risk } & \multirow[t]{2}{*}{$\mathbf{P}$} & \multirow[t]{2}{*}{ OR } & \multicolumn{2}{|c|}{ CI $95 \%$} & \multirow{2}{*}{$\begin{array}{l}\text { OR } \\
\text { adjusted }\end{array}$} & \multicolumn{2}{|c|}{$\begin{array}{l}\text { CI 95\% } \\
\text { adjusted }\end{array}$} \\
\hline & & & & & $\mathbf{L L}$ & UL & & $\mathbf{L L}$ & $\mathbf{U L}$ \\
\hline HTN & $14(43.8 \%)$ & $18(64.3 \%)$ & 0.112 & 2.314 & 0.817 & 6.559 & 0.415 & 0.050 & 3.415 \\
\hline BMI & $34.55 \pm 5.58$ & $37.42 \pm 5.18$ & $0.045^{*}$ & 1.107 & 0.999 & 1.225 & 1.103 & 0.986 & 1.234 \\
\hline Insulin level & $21.86 \pm 14.89$ & $35.41 \pm 18.56$ & $<0.001^{*}$ & $1.048^{*}$ & 1.014 & 1.084 & $1.049^{*}$ & 1.003 & 1.098 \\
\hline HDL & $28.41 \pm 9.08$ & $23.89 \pm 10.26$ & 0.060 & 0.952 & 0.900 & 1.006 & 0.956 & 0.868 & 1.053 \\
\hline TG & $105.75 \pm 59.32$ & $109.18 \pm 61.49$ & 0.988 & 1.001 & 0.992 & 1.010 & 0.998 & 0.987 & 1.010 \\
\hline
\end{tabular}

OR: Odds ratio; CI: Confidence interval ;LL: Lower limit; UL: Upper Limit; *Statistically significant at $\mathrm{p} \leq 0.05$

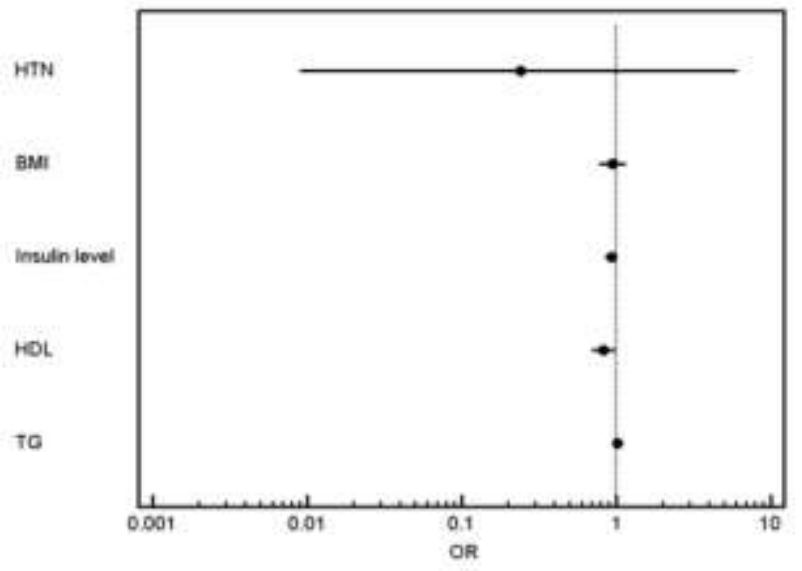

Figure 1: Forest blot for grade.

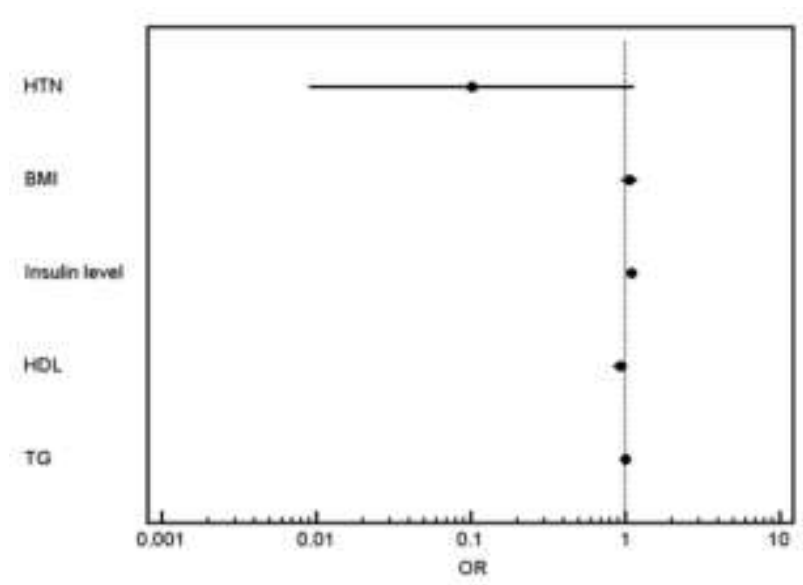

Figure 2: Forest plot for stage. 


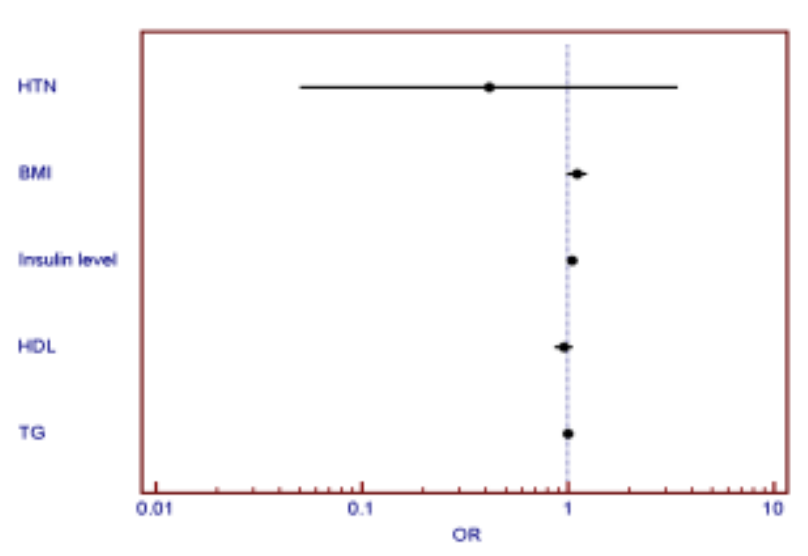

Figure 3: Forest plot for risk groups.

In Table 5, we study demographic features of endometrial cancer patients who were metformin users versus nonmetformin users irrespective to the other criteria of metabolic syndrome. Metformin users were statistically older and slightly heavier than non-metformin users. While there was a statically significant difference in stage distribution $(\mathrm{p}=0.028)$ i.e. non-metformin users presented at a lower stage.

Qualitative data were described using number and percent and was compared using Chi square test. Normally quantitative data was expressed as Mean \pm SD and compared using student t-test. While abnormally distributed data was expressed using Median (Min. Max.) and was compared using Mann Whitney test (Table 5).

\section{DISCUSSION}

Endometrial cancer (EC) is the most common female genital malignancy in developed countries, and the fourth most common cancer in women. ${ }^{14}$ Its incidence is growing worldwide due to increase in life expectancy, obesity prevalence and diabetes, both of which are increasing at alarming rates in the United States. ${ }^{15}$ Metabolic syndrome (MS) has become a major public health problem in several countries and represents a common clinical condition in countries with a high incidence of obesity and western dietary patterns. ${ }^{8}$

Table 5: Distribution of the studied cases according to metformin use.

\begin{tabular}{|c|c|c|c|c|c|c|}
\hline & \multicolumn{2}{|c|}{ On metformin ( $n=32)$} & \multicolumn{2}{|c|}{ No metformin $(\mathrm{n}=28)$} & \multirow{2}{*}{ Test of sig. } & \multirow{2}{*}{ p } \\
\hline & No. & $\%$ & No. & $\%$ & & \\
\hline \multicolumn{7}{|l|}{ Age } \\
\hline Min. - Max. & $46.0-76.0$ & & $43.0-74.0$ & & \multirow{3}{*}{$\mathrm{t}=1.319$} & \multirow{3}{*}{0.192} \\
\hline Mean \pm SD & $62.94 \pm 7.90$ & & $60.0 \pm 9.35$ & & & \\
\hline Median & 65.0 & & 62.0 & & & \\
\hline \multicolumn{7}{|l|}{ BMI } \\
\hline Min. - Max. & $25.80-48.0$ & & $25.0-44.50$ & & \multirow{3}{*}{$\mathrm{t}=0.458$} & \multirow{3}{*}{0.649} \\
\hline Mean \pm SD. & $36.20 \pm 6.24$ & & $35.54 \pm 4.71$ & & & \\
\hline Median & 36.10 & & 36.0 & & & \\
\hline \multicolumn{7}{|c|}{ Duration of usage of metformin } \\
\hline$<10$ years & 4 & 12.5 & - & - & & \\
\hline$>10$ years & 28 & 87.5 & - & - & & \\
\hline \multicolumn{7}{|l|}{ Stage } \\
\hline Stage I & 14 & 43.8 & 20 & 71.4 & \multirow{3}{*}{$\chi^{2}=7.132^{*}$} & \multirow{3}{*}{$0.028^{*}$} \\
\hline Stage II & 7 & 21.9 & 6 & 21.4 & & \\
\hline Stage III & 11 & 34.4 & 2 & 7.1 & & \\
\hline \multicolumn{7}{|l|}{ Risk } \\
\hline Low risk & 11 & 34.4 & 12 & 42.9 & \multirow{3}{*}{$\chi^{2}=4.455$} & \multirow{3}{*}{${ }^{\mathrm{MC}} \mathrm{p}=0.105$} \\
\hline Intermediate risk & 19 & 59.4 & 10 & 35.7 & & \\
\hline High risk & 2 & 6.3 & 6 & 21.4 & & \\
\hline
\end{tabular}

*Statistically significant at $\mathrm{p} \leq 0.05$

Epidemiologic studies have reported associations of EC risk with individual components of the MS, including obesity, type 2 diabetes, and hypertension. ${ }^{5}$

In our study, endometrial cancer patients having metabolic syndrome were significantly older than EC patients without MS $(64.28 \pm 6.51)$ years, and (58.46 \pm 9.83) respectively $(\mathrm{p}<0.05)$. This is in accordance to Esposito $\mathrm{K}$ et al EC occurred in elder age group patients with MS, thus more likely to be menopausal, with statically significant difference than group without MS in which $28 \%$ premenopausal which is coordinated with 
Lentz GM et al, which reported that endometrial cancer may affect premenopausal women (20-25\%) of cases. ${ }^{16,17}$

In the present study, endometrial cancer patients having metabolic syndrome had higher body mass index (BMI) but with no significant difference (36.51 \pm 5.53) compared to group $2(35.17 \pm 5.57)$. Dashti SG et al found that $7.5 \%$ of endometrial cancer patients had normal BMI 2 years before diagnosis compared to $29.6 \%$ among the control group. ${ }^{18}$ They reported that overweight was reported in $1.5 \%$ and obese in $6.8 \%$ of the endometrial cancer patients.

In the present study, patients with endometrial cancer having metabolic syndrome presented in higher grades. As grade II include $21(65.6 \%)$ of cases in group 1 while $8(28.6 \%)$ cases in group 2 with statistically significant difference $(\mathrm{p}<0.05)$ and also presented in higher stages of cancer as $56.2 \%$ group 1 versus $28.6 \%$ group 2 but with no statistically significant difference.

Most of the cases in our study presented in stage I as endometrial cancer are presented early by abnormal uterine bleeding. This is in according with Jhang $\mathrm{H}$ et al reported that $75 \%$ of patients presenting with stage I disease. $^{19}$

In our study we found that ER $\alpha$ expressed mostly in women without MS in early stage as, 18 (75\%) versus 15 (65\%) cases with MS, but with no significant difference, this matched with Jongen $\mathrm{V}$ et al. ${ }^{20}$ A large cohort of EC patients, ER- $\alpha$ was related to early stage, lower-grade tumors.

In our study to study the influence of different parameters of metabolic syndrome which include (BMI, HTN, Insulin level (hyperinsulinemia), HDL and TG) on aggressiveness of endometrioid endometrial cancer as regard (grade, stage and risk classification) and for the feasibility of statistical analysis, all EC cases were joined in one group then re-classified.

In the present study, insulin level was found to be an important factor affecting stage as when insulin level increase by one Uiu/ml the stage increase by $1.091 \%$ $(\mathrm{P}=<0.001, \mathrm{OR}=1.064$, OR adjusted $=1.091)$. As more hyperinsulinemia, the aggressiveness of tumour as regard stage increase, in accordance with our findings Steiner E, et al reported that patients with DM type II (insulin resistance) had a higher FIGO stage at diagnosis compared to patients without DM. ${ }^{21}$ This is also in accordance to Zandersa $\mathrm{M}$ et al. ${ }^{22}$ In addition, $\mathrm{Mu} \mathrm{N}$ et al reported that insulin resistance plays a central role in endometrial cancer, which matching with our study. ${ }^{23}$

Arcidiacono B et al stated that hyperinsulinism is a marker of insulin resistance and alters metabolic cell functions which consequently trigger several biochemical changes and cause endometrial hyperplasia via two pathways. $^{24}$ In the first one, insulin stimulates adrenal glands in postmenopausal women to produce more ovarian testosterone which is metabolized to estrogen in adipose tissue; insulin reduces serum level of circulating sex hormone binding globulin and thus leads to hyperestrogenemia. The second mechanism is reduction in insulin- like growth factor- binding protein (IGFBP) which increases IGF-1 which stimulates endometrium and causes endometrial hyperplasia and carcinogenesis.

Also we found that insulin level is most important factor affecting risk group as when insulin level increase by one $\mathrm{Uiu} / \mathrm{ml}$, the risk increase by $1.049 \%$ $(\mathrm{P}=<0.001, \mathrm{OR}=1.048$ and $\mathrm{OR}$ adjusted $=1.049)$.

Moreover, HDL was important factor affecting grade as when HDL decrease by one $\mathrm{mg} / \mathrm{dl}$, the grade increase by $0.033 \%(\mathrm{P}=0.030, \mathrm{OR}=0.899$, OR adjusted $=0.826)$, or by another word when HDL get higher, it's protective for risk of endometrial cancer. Zhang et al reported positive correlations of EC risk with TC, TG and LDL-C, but a negative correlation with HDL-C, which matched with our study. ${ }^{25}$

By studying all cases of endometrioid endometrial cancer we found that some patients were metformin users and some non-users irrespective to the other criteria of metabolic syndrome.

Metformin, classically used as an anti-diabetic medication, may serve as a new therapeutic agent for endometrial cancer. Metformin is a biguanide drug that was approved in the United States in 1994 and is currently used as the first line treatment for type II diabetes mellitus and preventing diabetes in patients with obesity and metabolic syndrome. ${ }^{26}$ Decensi A et al have suggested a protective role for metformin in the prevention of solid tumor malignancies in diabetic patients. ${ }^{27}$ Metformin likely exerts its anti-tumorigenic effects, through a combination of indirect mechanisms via increasing insulin sensitivity, inhibiting liver gluconeogenesis, and reducing hyperglycaemia and insulin levels; and direct mechanisms via activating AMP-activated protein kinase (AMPK). ${ }^{28}$

In our study we found, metformin users nearly equal nonmetformin users in our $60 \mathrm{EC}$ patients; while there was significant difference in stage distribution (Stage I: $43.8 \%$ vs. $71.4 \%$; Stage II $21.9 \%$ vs. $21.4 \%$; stage III: $34.4 \%$ vs. $7.1 \%$ ) between metformin and non-metformin users, respectively $(\mathrm{p}<0.001) .{ }^{28}$ Which mean metformin users presented in higher stage than non-users.

This in accordance with, Becker $\mathrm{C}$ et al who used a casecontrol design to evaluate the risk of developing endometrial cancer in metformin versus sulfonylurea users, to examine the relationship of metformin upon the risk of developing $\mathrm{EC}$, and neither found to have a protective effect. $^{29}$ 
Our findings are also consistent with those of a recently published meta-analysis by Stevens RJ et al on metformin compared to alternative oral hypoglycemics or usual care, which did not show a protective effect against endometrial cancer progression. ${ }^{30}$

\section{CONCLUSION}

Endometrial cancer patients with MS presented with higher grade, higher stage and high risk group than patients without MS. Hyperinsulinemia was the most important factor affecting aggressiveness of the tumor as regards stage and risk group classification. ER expression is used to identify endometrial cancer (EC) patients that could benefit of hormone therapy (low risk group), but with no significant between patients with MS and without MS. Furthermore, the information provided here may support further validation will be required before ER are incorporated in routine management of EC patients. Metformin failed to show a protective effect against endometrial cancer progression. More studies are needed for understanding role of metformin on stage and grade of EC due to contradictory results between studies.

Funding: No funding sources

Conflict of interest: None declared

Ethical approval: The study was approved by the Institutional Ethics Committee

\section{REFERENCES}

1. Hoffman B, Schaffer JO, Halvorson JI, Bradshaw KD. In Endometrial Cancer. Williams Gynecology: Chapter 33, Cunningham FG (eds), ( $2^{\text {nd }}$ ed) McGraw-Hill, ISBN 2012; 978.

2. Kong A, Johnson N, Kitchener HC, Lawrie TA. Gynecological Cancer Group. Adjuvant radiotherapy for stage I endometrial cancer. Cochrane Database of Systematic Reviews. 2012.

3. Kaaks R, Lukanova A, Kurzer MS. Obesity endogenous hormones and endometrial cancer risk a synthetic review. Cancer Epidem BioPrev. 2002;11:1531-43.

4. Berstein LM, Tchernobrovkina AE, Gamajunova VB. Tumor estrogen content and clinic morphological and endocrine features of endometrial cance. J Cancer Res Clin Oncol. 2003;129:245-9.

5. Weiderpass E, Persson I, Adami HO, Magnusson C, Lindgren A, Baron JA. Body size in different periods of life diabetes mellitus hypertension and risk of postmenopausal endometrial cancer (Sweden). In: Cancer Causes Control. 2000;11:185-92.

6. Anderson KE, Anderson E, Mink PJ, Hong CP, Kushi LH, Sellers TA, et al. Diabetes and endometrial cancer in the Iowa women's health study. Cancer Epidemiol Biomarkers Prev. 2001;10:611-9.

7. Aguilar-Salinas CA, Rojas R, Gómez-Pe'rez FJ, et al. The metabolic syndrome: a concept hard to define. Arch Med Res. 2005;36(3):223-31.
8. Alberti KG, Eckel RH, Grundy SM, Zimmet PZ, Cleeman JI, Donato KA, et al. Harmonizing the metabolic syndrome: a joint interim statement of the international diabetes federation task force on epidemiology and prevention; national heart, lung, and blood institute; American Heart Association; World Heart Federation; International Atherosclerosis Society; and International Association for the Study of Obesity. Circulation. 2009;120:1640-5.

9. Giovannucci E, Harlan DM, Archer MC, et al. Diabetes and cancer: a consensus report. CA: A Cancer Journal for Clinicians. 2010;60(4):207-21.

10. Johnson JA, Carstensen B, Witte D, Bowker SL, Lipscombe L, Renehan AG. Diabetes and cancer (1): evaluating the temporal relationship between type 2diabetes and cancer incidence. Diabetologia. 2012;55(6):1607-18.

11. Renehan AG, Yeh HC, Johnson JA, Wild SH, Gale EA, Moller H. Diabetes andcancer (2): evaluating the impact of diabetes on mortality in patients withcancer. Diabetologia. 2012;55(6):1619-32.

12. Bjorge T, Stocks T, Lukanova A, Tretli S, Selmer R, Manjer J, et al. Metabolic syndrome and endometrial carcinoma. Am J Epidemiol. 2010;171:892-2.

13. Birks JW (Ed.), Chemilumeniscence and Photochemical Reaction Detection in Chromatography, VCH Verlag Weinhein, Germany, 1989.

14. Strom BL, Schinnar R, Weber AL, Bunin G, Berlin JA, Baumgarten $M$, et al. Case-control study of postmenopausal hormone replacement therapy and endometrial cancer. Am J Epidemiol. 2006;164(8):775-86.

15. Ko EM, Walter P, Clark L, Havrilesky LJ, Alvarez Secord A, et al. Redefining obesity, diabetes, and race in type I and type II endometrial cancers. In: Oncologists SG, (ed). Society of Gynecologic Oncologists Annual Meeting for Women's Cancer. Los Angeles: Society of Gynecologic Oncologists. 2013;130(1):83.

16. Esposito K, Chiodini P, Capuano A, Bellastella G, Maiorino MI Giugliano D. Metabolic syndrome and endometrial cancer: a Meta-analysis. Endocrine. 2014;45:28-36.

17. Lentz GM, lobo RA, Gershenson DM. Endometrial cancer. In: Zaino RJ, Diehl SJ, Gajewski WH (eds.). Katz Comprehensive Gynecology. 5thed. Philadelphia: Mosby Elsevier; 2007:464-70.

18. Dashti SG, Chau R, Ouakrim DA, Buchanan DD, Clendenning M, Young JP, et al. Female Hormonal Factors and the Risk of Endometrial Cancer in Lynch Syndrome. JAMA. 2015;314(1):61-71.

19. Jhang H, Chuang L, Visintainer P, Ramaswamy G. CA 125 levels in the preoperative assessment of advanced-stage uterine cancer. Am J Obstet Gynecol. 2003;188(5):1195-7.

20. Jongen V, Briet J, de Jong R, ten Hoor K, Boezen M, van der Zee A, et al. Expression of estrogen receptoralpha and -beta and progesterone receptor-A and -B 
in a large cohort of patients with endometrioid endometrial cancer. Gynecol Oncol. 2009;112(3):537-42.

21. Steiner E, Eicher O, Sagemüller J, Schmidt M, Pilch $\mathrm{H}$, Tanner B, et al. Multivariate independent prognostic factors in endometrial carcinoma: a clinicopathologic study in 181 patients: 10 years' experience at the Department of Obstetrics and Gynecology of the Mainz University. Int J Gynecol Cancer. 2003;13(2):197-203.

22. Zandersa M, Dorry B, Liza N, Van S, Lonneke V, Harm R, et al. Effect of diabetes on endometrial cancer recurrence and survival . Maturitas. 2013;74:37-43.

23. Mu N, Zhu Y, Wang Y, Zhang H, Xue F. Insulin resistance: a significant risk factor of endometrial cancer. Gynecol Oncol. 2012;125:751-7.

24. Arcidiacono B, Iiritano S, Nocera A, Possidente K, Nevolo MT, Ventura V, et al. Insulin resistance and cancer risk: an overview of the pathogenetic mechanisms. Exp Diabetes Res. 2012;789174.

25. Zhang Y, Liu Z, Yu X, Zhang X, Lü S, Chen X. The association between metabolic abnormality and endometrial cancer: a large case-control study in China. Gynecol Oncol. 2010;117(1):41-6.
26. Giovannucci E, Harlan DM, Archer MC, Bergenstal RM, Gapstur SM, Habel LA, et al. Diabetes and cancer: a consensus report. Diabetes Care. 2010;33:1674-85.

27. Decensi A, PuntoniM, Goodwin P, Cazzaniga M, Gennari A, Bonanni B, et al. Metformin and cancer risk in diabetic patients: a systematic review and meta-analysis. Cancer Prev Res (Phila). 2010;3:1451-61.

28. Ratner RE, Christophi CA, Metzger BE, Dabelea D, Bennett PH, Pi-Sunyer X, et al. Prevention of diabetes in women with a history of gestational diabetes: effects of metformin and lifestyle interventions. J Clin Endocrinol Metab. 2008;93:4774-9.

29. Becker C, Jick SS, Meier CR, Bodmer M. Metformin and the risk of endometrial cancer: a case-control analysis. Gynecol Oncol. 2013;129:565-9.

30. Stevens RJ, Ali R, Bankhead CR, Bethel MA, Cairns BJ, Camisasca RP, et al. Cancer outcomes and allcause mortality in adults allocated to metformin: systematic review and collaborative meta-analysis of randomized clinical trials. Diabetologia. 2012;55:2593-603.

Cite this article as: Tawfik TA, Elsabaa BM, ElNeily DA, El-Tawab SS, Ebrahim HA. The impact of metabolic syndrome on the clinical profile and tumor characteristics of endometrial carcinoma. Int $\mathrm{J}$ Reprod Contracept Obstet Gynecol 2016;5:36963703. 